\title{
Gap Junction Beta-2 Protein
}

National Cancer Institute

\section{Source}

National Cancer Institute. Gap/unction Beta-2 Protein. NCI Thesaurus. Code C127001.

Gap junction beta-2 protein (226 aa, $\sim 26 \mathrm{kDa}$ ) is encoded by the human GJB2 gene. This protein plays a role in gap junction-mediated facilitated diffusion. 